\title{
ESL Teachers' Attitudes towards Using ICT in Literature Lessons
}

\author{
Parilah Md. Shah \\ Faculty of Education, Universiti Kebangsaan Malaysia \\ 43600 Bangi, Selangor Darul Ehsan, Malaysia \\ Tel: 60-12-315-1362Ｅ-mail: drparila@gmail.com \\ Joscyln L. Empungan (Corresponding author) \\ Faculty of Education, Universiti Kebangsaan Malaysia \\ 43600 Bangi, Selangor Darul Ehsan, Malaysia \\ Tel: 60-13-804-2820 E-mail: icedjolem@yahoo.com
}

Received: February 11, 2015 Accepted: February 25, 2015 Published: February 25, 2015

doi:10.5296/ijele.v3i1.7158 URL: http://dx.doi.org/10.5296/ijele.v3i1.7158

\begin{abstract}
Literature component has been a part of the English Syllabus in Malaysian secondary schools and the learning of literature in English is not easy. To improve the quality of teaching English Literature, over the years the integration of Information and Communication Technology (ICT) in the teaching of literature is seen as an important aspect. However, past studies suggests that effective integration depends on teachers' attitudes and skills in using ICT. Depending on the fact that teachers' attitude is a major predictor in the process of ICT integration, this study investigated the attitudes of English teachers in Sarawak towards ICT. The proposed study will use quantitative methods to find out teachers' ICT usage and their attitudes towards it. It further seeks the problems and challenges that may hinder the use of ICT in literature lessons. For that purpose, 30 English teachers from various secondary schools in the state of Sarawak have been selected as the sample. They were given questionnaires and SPSS for Microsoft Windows was used to complete the analysis of the collected data. The study revealed that ICT is used on the satisfactory level by the teachers. In addition, the teachers possessed an acceptable positive attitudes towards the use of ICT tools in Literature lessons. However, the analysis of the data also showed several challenges that might hamper the possibility of using ICT in Literature lessons. To conclude, there should be more actions that should be taken to promote the use of ICT in Literature lessons in the future.
\end{abstract}

Keywords: attitude, challenges, ICT, literature component, Malaysian secondary schools, teachers 


\section{Introduction}

In Malaysian secondary schools, the teaching and learning of English Literature began since the year 2000 and has evolved over the time. The incorporation of literature in the English syllabus is seen as an important aspect to help learners engage in a wider reading of good works and for enjoyment and self-development. The students are taught on four different genres including the poem, short story, drama and also novel. Currently, the students are learning the third set of the prescribed texts, starting from the year 2015.

Chacko (2007) in his study stated that learning literature is not easy and since the implementation of literature in the English syllabus, a lot of responses and concerns come from various parties including the students and the teachers. Students with low English language proficiency or students who lack in terms of the language repertoire do not welcome English literature. Literature lessons require the students to show their appreciation and not only about the understanding of the text (Melor \& Ashairi, 2014). Due to their inability to comprehend the texts, they are not able to proceed to a more challenging activity. They become students who are passive in the classroom and merely act as listeners as they expect teachers to be the one doing all the talking throughout the learning process and at the same time, leaving it all to the teachers to make the Literature lesson a meaningful and interesting one. To make matters worse, in a study conducted by Marzilah and Sharifah Nadia (2010) it is revealed that most teachers do not know the best method or approaches to teach Literature. This shows that there is a possibility that the methods normally used during Literature lesson may not be suitable to the students' understanding and a not interesting method employed by the teachers can cause students to show disinterest in learning the Literature lessons. Thus, it is not surprising to find increasing interest, attention and investment put into the use of information and communication technology (ICT) in the teaching and learning process as ICT has proven to raise educational quality and it has the ability to connect to real-life situations and transforming a teaching environment into a learner-centered one ( $\mathrm{Fu}, 2013)$.

The use of ICT brings about a creative and great learning environments and according to Volman and Eck (2001) as cited by Singh and Chan (2014), it is able to transform the teaching and learning process in such a way that it presents knowledge in an active, self-directed and constructive way. ICT is not only considered as a tool but also as an instrument to support new ways of teaching and learning process. Adding to this, the Malaysia Government has developed the Education Blueprint 2013-2025 which specifies a comprehensive plan for a rapid transformation of our education system. A maximize use of ICT for distance and self-paced learning to expand capacity and allow for more customized learning is one of the strategy to scale up quality learning across Malaysia (Ministry of Education Malaysia, 2012). Clearly, it is the Government's aspiration of ensuring teaching and learning process are on par with the $21^{\text {st }}$ century education.

The use of ICT in the classroom for the teaching and learning is very important to provide opportunities for students to learn and operate in the information age. However, successful integration of ICT in teaching and learning process is highly dependent on the preparation and attitudes of teachers. Undeniably that there are ICT tools available and easily accessible 
by the teachers but even with the existence of the tools, teachers still failed to fully utilize ICT into their lessons. And, if they do utilize these tools, most employed the use of ICT in teaching language skills and even fewer studies paid attention to teachers' attitudes in using ICT in literature lessons. One of the factors that determine the development and innovation in public education is the teachers because they are the people who use ICT investment for the development of education. The presence of technology in classroom creates pressure (Kozma, 2003 in Singh and Chan, 2014) and it is also related to teachers' attitudes towards the use of ICT.

Hence, this article serves as the platform to find out the attitudes towards using ICT in teaching Literature lessons among ESL teachers focusing on those currently teaching in Sarawak. An examination of the demographic features of teachers in connection with ICT attitude is also included to have a detailed understanding on the topic. Specifically, the following questions have guided this study:

1) What are the teachers' attitudes in the usage of ICT tools in teaching Literature?

2) What are the current level of ICT usage in teaching English Literature component among the English teachers?

3) What are the challenges or problems in using ICT tools in teaching English Literature component?

\section{Literature Review}

\subsection{Literature in English in the Malaysian curriculum}

The teaching of literature in English in the Malaysian curriculum includes the development and enhancement of the basic language skills that are used in a literature in ESL context. One of the most important skills that can be developed in the study of literature is reading. The process of reading literature requires that a student engage with literary texts based on their past experiences, knowledge and worldview. In addition, Literature component is considered the most successful reading programme because it is a tested component in the public examinations (Vethamani, 2004 in Ashairi \& Melor, 2014). Students would be able to acquire the skill of expressing their understanding and views of issues and themes portrayed in literary texts from the dynamic reading, thinking and interpreting process. A study by Marzilah and Sharifah Nadia (2010) indicated that with the exposure to texts of various genres and cultural contexts, students would also learn about intercultural engagement from literary texts that portray cultural and ideological differences. Hence, the learning of Literature provides a space for students for critical engagement with issues, themes and text constructions that are authentic and relevant in the real world. Literature learning would expose students to different texts and contexts as literary texts are not only rich resources for language learning but importantly, sites for the development of critical thinking skills.

Literature is taught to enhance students' proficiency in the English language and at the same time it is also to be enjoyed. It may not be easy to strike a balance between making sure that Literature be the tool to promote literacy and be the tool for pure enjoyment but it is also not 
impossible to be achieved. In order to teach Literature to students, there are several ways to deliver the content of Literature and to ensure that students both enjoy and able to learn something from it. In a study by Marzilah and Sharifah Nadia (2010), it is found that teachers merely explain and opted for answering comprehension questions techniques or in other words the teachers only manage to teach Literature by using the traditional method. This way of teaching Literature is rather boring to the students and not to mention it only focuses on the pronunciation and vocabulary aspect of learning Literature. Siti Norliana, Roszainora, Muthusamy and Kamaruzaman (2009) stated in their study that there are three most common teaching approaches in Literature. The first is teaching for content which usually means learning Literature for its linguistic aspect. Students are normally required to have experiential knowledge in order to discuss the texts. The second is teaching for personal enrichment. This aim to encourage students to be more involved in the learning process because they are need to relate what they learn to their own experiences. The third approach is the language-based approach. This approach is used to make students more aware of the language used in the literature texts. Regardless of the teaching approaches opted by the teachers to teach Literature, one thing which is important is that it should be about improving students' proficiency in the English language and also to be enjoyed. In addition, teachers should employ approaches which suit their students' preference and interest. This is true because students favour teaching techniques that encourage them to speak their mind about the content of the text as opposed to purely learning Literature by analyzing its language structure. Fauziah and Jamaluddin (2009) in their study showed that the teachers used more student-centered approach which in turn created a better learning environment and improved students' perception and motivation to learn Literature. Hence, in order to allow such environment in Literature lessons, ICT is seen as the tool that encourages positive impact on students' learning process. ICT is also a tool that is capable to encourage the students to think critically, solve problems and be motivated to learn Literature (Nur Aisyah, Zamri, Afendi \& Mohamed Amin Embi, 2012).

\subsection{The Use of Information and Communication Technology (ICT) in Education}

The term ICT stands for information and communication technology. It embraces a range of technical media from hardware (computers, laptops, tablets, mobile phones, projection technology and digital audio and visual equipment), software applications (generic software and multimedia resources) to information systems (Internet and cloud computing). The integration of technology into the process of teaching and learning is thought to increase students and teachers productivity and at the same time it allows both teachers and students to find mounds of information they need for the lessons (Al-Zaidiyeen, Leong \& Fong, 2010).

In traditional teaching and learning method, teachers often focus on transferring knowledge, skills and values to students via lectures and the standard questions-and-answers segments and students are expected to listen and answer when required and read textbooks. While teachers are seen passionate about the subject that they are teaching, the student learning has become passive. Therefore, this method of teaching is often characterized as poor teaching technique. ICT, on the other hand, offers something different to the art of teaching and learning in the classroom. It provides resources for learning which are more effective, richer, 
and available for extended hours and open to a wider range of students. Alessi and Trollip (2001) as cited in Nair et. al. (2012) stated that using computers to teach in the classroom is always better than using books or other traditional methods. This is because, if ICT tools or any related technology are being used appropriately, it could facilitate independence and positive orientation towards learning. And so, the success or failure of using ICT tools in classrooms depends largely on the person using it; the teachers. However, by no means are these teachers should be coerced into using ICT tools but they should be encourage to be willing users themselves. In a study by Hennessy, Harrison and Wamakote (2010), they indicated two reasons for teachers to use ICT, the first being, teachers see that their own use of computers benefits their learners greatly and secondly, teachers feel learners could benefit from using the computers. In addition, it is also found that ICT has a lot of advantages and one of the principal advantage of the use of ICT in teaching and learning is that ICT enables schools to cater for the needs of the individual. The second advantage is that ICT can dramatically improve access to information for and communication of ideas by the students. The third benefit is that ICT can be used to enhance student learning. The difficult concepts can be made simpler when illustrated with animated graphics and computer simulations. Students can also access high quality information more easily using Internet servers. In other words, teachers will be inclined to use ICT in the classrooms if they see that ICT is useful and advantageous.

At the same time, we must also acknowledge the fact that implementing ICT in teaching and learning is a lot easier said than done. There are several challenges along the way that hinders the use of ICT. It is a common misconception that access to technology on its own motivates teachers to apply it in their teaching. The biggest barriers to the use of ICT in teaching were the lack of time available to classes, teachers' lesson planning and the lack of national policy on the use of ICT in teaching and learning (Hennessy et. al., 2010). Little structural support from school administrators and rigid curriculum were also some of the prominent factors hindering teachers' use of ICT. Schools usually gives little time for teachers to manage and get familiarize themselves with ICT not to mention lack of administrative support for teachers who are not confident enough to commence ICT. In addition to this, levels of teachers' own expertise in getting familiarize with these ICT tools, inadequacy of learning resources and learning materials and their attitudes are also the factors in hindering the use of ICT. However, the teachers' attitudes to ICT use in learning far outweighed the institutional or school factors (Oldfield, 2010). Teachers' use of ICT is influenced greatly by their attitudes towards the way the subject should be taught and by the skills associated with their competence in managing classroom activities and their computer handling technical skills. Clearly, to encourage ICT use, the actual acceptance depends largely on teachers' personal feelings and attitudes to ICT in general. More details will be describe further in the next section.

\subsection{Teachers' Attitudes towards the Use of ICT in Literature Lesson}

Attitudes are thought to consist of three elements: affect, cognition and behavior (Albirini, 2006). Affective element is related to the individuals' emotional case; cognitive element refers to the individuals' knowledge and behaviour element is the overt behaviour. Attitudes 
toward ICT usage have been defined as a person's general feelings towards ICT and specific computer and Internet related activities (Smith, Caputi \& Rawstone, 2000 in Abedalaziz, Sharir \& Chin, 2013). In order to have an exact understanding about one's attitude, all these elements should be taken into consideration.

In order to achieve full use of ICT in Literature lessons, teachers' attitudes is seen as one of the obvious factor. Albirini (2004), stated that attitudes are considered as a major predictor to the use of new technologies in the classrooms. It can also be related to the amount of ICT being used by the teachers. Thus, attitudes play an important role in shaping ones reactions to situations. Attitude is an emotion that prepares an individual to respond consistently in a favourable and unfavourable manner when confronted with a particular object (Fishbein, 1967 in Al-Zaidiyeen et. al., 2010). Attitudes, behaviour and feelings have been found by some researchers to be linked, such that people's attitudes determine their behaviour towards object and people they meet and influence even the relationships that exist among this with them (Melor, Maimun \& Chua, 2009). From these features we may describe attitude as a complex, mostly learned and enduring but changeable system of cognition and affection which influence an individual's favourable and unfavourable action or reaction to an object. Attitude is likely a personal factor which could influence the person on the use of ICT. This is because the person's attitude may directly influence their attention to use the computer or ICT.

Teachers will be in a position to use ICT tools and resources effectively in the classroom only when they realize how useful these tools are in presenting materials to the students and overall learning process. The influence of ICT in teaching and learning is largely based on the perceptions and attitudes of the teachers who are responsible for using this technology (Joseph, 2013). Joseph continued by stating that teachers' views brought a strong impact to the integration of computers in the classrooms and that teachers needed to be encouraged to continuously explore the usefulness of ICT in the classrooms. A research by Melor, Norazah, Salehi, Mohamed Amin Embi and Salehi (2014) on Future of ICT as a Pedagogical Tool in ESL Teaching and Learning was done among the ESL teachers in secondary schools in Malaysia through semi structured interviews with teachers. The aim of this study was to know the teachers' perception of the future of ICT as a pedagogical tool. The findings indicated that majority of the teachers had positive attitudes towards using ICT in teaching ESL, which includes the teaching of Literature.

During the process of combining ICT with education, teachers' attitude towards using knowledge besides their talent and desire will be a crucial point affecting the results of application. The basic agent for establishing and working this system is the teachers. It is argued that successful integration of ICT in education enables teachers to transform instruction from teacher-centered to student-centered where learners may interact with their peers and use the computers and Internet for their own learning needs.

\section{Methodology}

\subsection{Research Design}


The present study utilized quantitative methodology. It employed the use of questionnaire as the research instrument. The data collection was based on the questionnaire distributed to the respondents and this served as the primary instrument. The questionnaire was designed in order to accumulate enough information pertaining to the objectives of the study.

\subsection{Sample}

The respondents for this study were selected in accordance with convenience sampling procedure. Cresswell (2014) stated that convenience sampling procedure is a quantitative procedure in which the researcher selects participants because they are willing and available to be studied. The study was conducted at 6 secondary schools in Sarawak. The participants of this research study were 30 secondary school teachers who teach the English Literature component for Form $1-5$ classes. All the teachers attending to the study are working at public schools. The participants comprised of 20 females and 10 males. The subjects' ages ranged from 21 to 60 years old.

\subsection{Research Instrument}

The survey method was followed to collect the data on ICT adoption of Sarawak ESL teachers. The data collection instrument was a questionnaire adopted and adapted from Albirini (2006); Papanastasiou and Angeli (2008) and Almaghlouth (2008). The questionnaire was divided into five parts. Part 1 asks about the demographic features such as gender, age, teaching experience, computer ownership and professional development courses. Part 2 is designed to learn about teachers' attitude and contains 15 statements in a four point scale from strongly disagree to strongly agree. Part 3 includes level of ICT usage among the participants. The last part includes 10 statements with regard to the challenges or problems faced by the respondents which was represented by a four point scale ranging from 1 (Strongly disagree) to 4 (Strongly agree).

\subsection{Data Analysis and Procedures}

The data gathered from the respondents were analysed for the purpose of answering the research questions. The questionnaires were analysed using the descriptive statistics in order to collect the frequency count and percentages. They were presented in the form of tables. Demographic variables of the respondents were also collected to support data to understand the overall analysis. The data analysis utilized was the Statistical Package Social Science (SPSS).

\section{Findings}

\subsection{Demographic Background}

Most of the respondents in this survey group were females who represented $66.7 \%$ of the sample and $33.3 \%$ of the respondents were males. As for the teaching experience, $33.3 \%$ have been teaching for less than 5 years, $36.7 \%$ for less than 10 years and $16.7 \%$ have been teaching for more than 16 years. The majority of the respondents which comprised of $63.3 \%$ have attended formal training and $36.7 \%$ of them did not receive any formal training related to the integration of ICT in teaching and learning. 
Table 1. Gender

\begin{tabular}{|l|l|l|}
\hline Gender & Number of respondent & Percentage (\%) \\
\hline Male & 10 & 33.3 \\
\hline Female & 20 & 66.7 \\
\hline
\end{tabular}

Table 2. Teaching Experience

\begin{tabular}{|l|l|l|}
\hline Teaching experience (years) & Number of respondent & Percentage (\%) \\
\hline $1-5$ & 10 & 33.3 \\
\hline $6-10$ & 11 & 36.7 \\
\hline $11-15$ & 1 & 3.3 \\
\hline $16-20$ & 5 & 16.7 \\
\hline $21+$ & 3 & 10 \\
\hline
\end{tabular}

Table 3. Formal training on ICT received

\begin{tabular}{|l|l|l|}
\hline Any formal training? & Number of respondent & Percentage (\%) \\
\hline Yes & 19 & 63.3 \\
\hline No & 11 & 36.7 \\
\hline
\end{tabular}

\subsection{Teachers' Attitudes towards the Use of ICT Tools in Literature Lessons}

Research Question 1: What are the teachers' attitudes towards the use of ICT tools in Literature Lessons?

Each item was rated from Strongly Disagree, Disagree, Agree and Strongly Agree. Table 4 presents the results among the respondent's attitudes towards the use of ICT in the teaching of Literature. This section will present the findings on teachers' attitudes towards the use of ICT tools, as tabulated in Table 4. It seemed that the teachers have an average positive attitude towards the use of ICT tools. The results showed among the 6 positive items, the range from $66.7 \%$ to $46.7 \%$ agreed while among the 9 negative items, the range from $56.7 \%$ to $40 \%$ disagreed. From this, it could be interpreted that teachers felt positive towards the use of ICT tools. A high percentage of teachers agreed (66.7\%) and strongly agreed $(23.3 \%)$ on the item such as 'using ICT tools will change the way I teach the Literature components'. Other item which denoted a high frequency was 'ICT helps students learn because it allows them to express their thinking in better and different ways' as $63.3 \%$ teachers agreed while another $23.3 \%$ strongly agreed. This demonstrated that the teachers are aware that ICT could make a difference in their teaching techniques. It also showed that the teachers had confidence in themselves to utilize the ICT tools in their teaching. This is supported by item 10 which showed a majority of the teachers (56.7\%) disagreed that the ICT tools are not 
conducive to good teaching while another $50 \%$ disagreed that ICT tools scares them or stresses them out.

Table 4. Attitudes towards ICT

\begin{tabular}{|c|c|c|c|c|}
\hline \multirow[t]{2}{*}{ Items } & \multicolumn{4}{|c|}{ Percentage $(\%)$} \\
\hline & SD & $\mathrm{D}$ & A & SA \\
\hline $\begin{array}{l}\text { I feel comfortable with the idea of ICT as a tool in teaching } \\
\text { and learning. }\end{array}$ & & 10 & 56.7 & 33.3 \\
\hline The use of ICT in Literature lessons stresses me out. & 30 & 50 & 20 & \\
\hline $\begin{array}{l}\text { The idea of using ICT tools in Literature lessons makes me } \\
\text { skeptical. }\end{array}$ & 30 & 43.3 & 26.7 & \\
\hline The use of ICT tools in Literature lessons scares me. & 40 & 50 & 10 & \\
\hline $\begin{array}{l}\text { Using ICT tools will change the way I teach the Literature } \\
\text { components. }\end{array}$ & & 10 & 66.7 & 23.3 \\
\hline $\begin{array}{l}\text { ICT tools are not conducive to student learning because it is } \\
\text { not easy to use. }\end{array}$ & 40 & 46.7 & 10 & 3.3 \\
\hline $\begin{array}{l}\text { ICT helps students understand concepts in more effective } \\
\text { ways. }\end{array}$ & & 3.3 & 56.7 & 40 \\
\hline $\begin{array}{l}\text { ICT helps students learn because it allows them to express } \\
\text { their thinking in better and different ways. }\end{array}$ & & 13.3 & 63.3 & 23.3 \\
\hline ICT tools help teachers to teach in more effective ways. & & 6.7 & 46.7 & 46.7 \\
\hline $\begin{array}{l}\text { ICT tools are not conducive to good teaching because it } \\
\text { creates technical problems. }\end{array}$ & 10 & 56.7 & 30 & 3.3 \\
\hline $\begin{array}{l}\text { ICT tools save time and effort in creating my Literature } \\
\text { lessons. }\end{array}$ & & 16.7 & 53.3 & 30 \\
\hline $\begin{array}{l}\text { I do not think I would ever need to use any ICT tools in my } \\
\text { Literature lessons. }\end{array}$ & 40 & 46.7 & 13.3 & \\
\hline I would rather do things by hand than with ICT tools. & 33.3 & 40 & 26.7 & \\
\hline I have no intention to use ICT tools in the near future. & 43.3 & 43.3 & 13.3 & \\
\hline ICT tools do more harm than good & 43.3 & 46.7 & 10 & \\
\hline
\end{tabular}

Note. $\mathrm{SD}=$ Strongly Disagree, $\mathrm{D}=$ Disagree, $\mathrm{A}=$ Agree, $\mathrm{SA}=$ Strongly Agree 


\subsection{Level of ICT Use in Literature Lessons}

Research Question 2: What are the current level of ICT usage in teaching English Literature component among the English teachers?

Table 5 shows the result of ICT used in Literature lessons by the teachers. When asked about the availability of ICT tools in their schools the range from $73.3 \%$ to $100 \%$ agreed that the tools are available. Interestingly, though, a rather small percentage of the teachers claimed to have students' computer at their schools. However, when it comes to utilizing these tools in the teaching and learning process, it gained lower percentage of teachers' agreement $(56.7 \%$ $93.3 \%$ ). Item 'Internet connection' only had $60 \%$ of the teachers claiming to utilize it in their lessons, similar with item 'web 2.0 applications' with only $56.7 \%$. Perhaps, these teachers have the ICT tools available and have the skills but they are lacking in terms of using the online applications as they are not exposed to the Internet and the Web 2.0 applications. There is also the possibility that these teachers do not how to integrate these online tools into their lessons.

For the purpose of finding out the frequency of using ICT tools, the respondents were asked to respond to a 4-Likert scale items (Never, Rarely, Sometimes and Often). The results shows that $43.3 \%$ and $36.7 \%$ of the teachers often use Microsoft Office and their computers or laptops in Literature lessons, respectively. $40 \%$ of the teachers sometimes use digital projector and $33.3 \%$ of the teachers either sometimes use or never use Web 2.0 applications in their literature lessons. As for using the internet connection in Literature lessons, 33.3\% reported that they rarely use it. A majority $(83.3 \%$ and $46.7 \%)$ of the teachers never use students' computer in the classroom and in the lab. When asked if the teachers have used ICT tools for the following activities, only $23.3 \%$ of the respondents often use their computer or laptop to deliver instruction in their literature lessons, similar to item 'Developing Literature lessons by designing informative PowerPoint slides'. As for performing research and lesson planning using internet browsers, creating or using animated cartoon presentations and using YouTube to create video clip of scenes related to the Literature texts, $20 \%, 6.7 \%$ and $13.3 \%$ of the respondents often use it, respectively.

Table 5. Level of ICT Use in Literature Lessons

\begin{tabular}{|l|l|l|}
\hline ITEMS & YES \% \\
\hline Which of the following & Digital projector & 86.7 \\
ICT tools are available in & TV monitor/VCR/DVD player & 83.3 \\
your school? & Scanner & 90 \\
& Printers & 100 \\
& Computer/Laptop for teacher use & 93.3 \\
& Students computer in a lab & 86.7 \\
& Students computer in classroom & 13.3 \\
& Internet connection & 76.7 \\
& Microsoft Office & 100 \\
\hline Which of the following & Web 2.0 applications & 73.3 \\
\hline
\end{tabular}


tools do you use for your Literature lessons?

\section{TV}

Scanner

Printers

Computer/Laptop for teacher use

Internet connection

Microsoft Office

Web 2.0 applications

\begin{tabular}{|l|}
\hline ITEMS \\
How often do you use \\
these tools in your \\
Literature lessons?
\end{tabular}

Literature lessons?

\section{Digital projector}

TV monitor/VCR/DVD player

Scanner

Dig

\begin{tabular}{|l} 
\\
$\begin{array}{l}\text { Have you used ICT tool } \\
\text { for the following }\end{array}$
\end{tabular} activities?
Printers

Digital Camera

Overhead projector

Computer/Laptop for teacher use

Students computer in a lab

Students computer in classroom

Internet connection

Microsoft Office

Web 2.0 applications

Using a computer/laptop to

deliver instruction to your

Literature lessons

Developing Literature lessons by designing informative PowerPoint slides

Perform research and lesson planning using the internet browsers

Creating/using animated cartoon presentations (i.e., Powtoon, Voki, etc.) that demonstrate real world interaction

Using YouTube to create video clip of scenes related to the Literature texts to explain the settings.
56.7

56.7

83.3

83.3

60

93.3

56.7

\begin{tabular}{|l|l|l|l|}
\hline $\mathrm{N}$ & $\mathrm{R}$ & $\mathrm{S}$ & $\mathrm{O}$ \\
\hline 6.7 & 36.7 & 40 & 16.7
\end{tabular}

16.7

\begin{tabular}{|l|l|l|l|}
33.3 & 36.7 & 26.7 & 3.3 \\
\hline
\end{tabular}

20

\begin{tabular}{l|l|l}
33.3 & 40 & 6.7
\end{tabular}

3.3

30

\begin{tabular}{l|l|l|}
30 & 46.7 & 20
\end{tabular}

$\begin{array}{lll}43.3 & 23.3 & 3.3\end{array}$

60

6.7

\begin{tabular}{l|l|l}
20 & 10 & 10
\end{tabular}

46.7

26.730

36.7

83.3

$23.3 \quad 30$

\begin{tabular}{l|l}
10 & 6.7
\end{tabular}

\begin{tabular}{|l|l|l|l|}
16.7 & 33.3 & 23.3 & 26.7 \\
\hline
\end{tabular}

6.7

33.3

$16.7 \quad 33.3$

43.3

33.3

$16.7 \quad 33.3$

16.7

6.7

16.7

53.3

23.3

6.7

\begin{tabular}{l|l|l}
13.3 & 56.7 & 23.3
\end{tabular}

13.3

20

46.7

20

40

43.3

e

Note. $\mathrm{N}=$ Never, $\mathrm{R}=$ Rarely, $\mathrm{S}=$ Sometimes, $\mathrm{O}=\mathrm{Often}$

\subsection{Challenges or Problems in the use of ICT tools in Literature Lessons}

Research Question 3: What are the challenges or problems in using ICT tools in Literature Lessons? 
The respondents have answered a 4 Likert-scale items to measure the challenges or problems faced by the respondents in using ICT in Literature lessons. Majority of the respondents $(83.3 \%)$ claimed that internet access which is normally either inaccessible or unavailable to be the problem of using ICT in the classrooms. Whereas, $80 \%$ of the respondents claimed that insufficient computers or ICT tools to be a challenge for the teachers and $76.7 \%$ stated that it is a problem that the schools have outdated or incompatible computers. Another challenge to using ICT tools in Literature lessons is because of insufficient time to master the software and to integrate ICT during a class period (73.3\%). In addition, large class sizes (71\%), lack of training and unreliable computers and software $(63.3 \%)$ are also some of the challenges in the use of ICT tools in Literature lessons.

Table 6. The Challenges in using ICT tools in Literature Lessons

\begin{tabular}{|l|l|l|}
\hline Items & \multicolumn{2}{l|}{ Percentage (\%) } \\
\cline { 2 - 3 } & $\begin{array}{l}\text { Strongly } \\
\text { Disagree \& } \\
\text { Disagree }\end{array}$ & $\begin{array}{l}\text { Agree \& } \\
\text { Strongly } \\
\text { Agree }\end{array}$ \\
\hline Not enough computers and/or ICT tools at my school & 20 & 80 \\
\hline Outdated/incompatible computers and/or other ICT tools & 23.3 & 76.7 \\
\hline Unreliable computers and/or software & 36.7 & 63.3 \\
\hline Internet access is either not easily accessible or unavailable & 16.7 & 83.3 \\
\hline $\begin{array}{l}\text { Insufficient time to master new software or integrate ICT } \\
\text { during a class period }\end{array}$ & 26.6 & 73.3 \\
\hline Classroom management with large class sizes & 30 & 71 \\
\hline Lack of training on available computers and/or software & 30 & 70 \\
\hline
\end{tabular}

\section{Discussions}

The current study investigated the attitudes of secondary school ESL teachers in Sarawak towards ICT tools and the possible challenges that could hinder ICT use in Literature lessons. The findings of the study can be summarized under 3 headings which are the attitudes that the teacher possess towards ICT, the level of ICT used for literature lessons and the challenges or problems faced by teachers in using ICT. The study could probably help to overcome these problems and hopefully the teachers could become successful technology adopters in the future.

The first finding is related to attitudes which demonstrate that teachers' attitude are averagely positive overall. These studies show that the majority of the respondents have positive attitudes towards the use of ICT in their Literature lessons. This is on par with the study by Cahyani and Cahyono (2012). This confirms that teachers were ready to use ICT as tools to help them improve their teaching of Literature lessons. Teachers should remember that these 
ICT tools have much to offer in terms of encouraging students to be interested in the Literature lessons. In fact, teachers should continuously vary their use of ICT tools and continuously use these tools so as to indirectly improve students' attitudes towards Literature lessons. The above findings also indicate that teachers believe that there is a possibility that ICT tools could somehow improve their teaching. It also shows that the teachers have rationally accepted that using ICT in their lessons could bring changes for the better in the teaching of Literature component. Moreover, ICT provides a variety of learning opportunities for students to learn language which includes the learning of Literature texts (Melor, 2007 in Melor, Maimun \& Chua, 2009). Thus, the majority of the respondents considered ICT tools as a viable educational tool that has the potential to bring about improvements to the way the students learn and understand difficult concepts in much more effective ways.

The second finding concerns about the level of ICT used for Literature lessons by the English teachers. The analyses revealed that most teachers used ICT tools to help with the general usage like delivering instructions in the class or for preparing PowerPoint slides. There is a possibility that the teachers have low familiarity on other ICT tools such as the internet and the Web 2.0 applications. This finding is parallel to a study by Ndibalema (2014) regarding teachers' lack of training from their teacher education colleges in terms of using ICT. In addition, they rarely incorporate online applications as part of the tools in teaching Literature. This result is compliance with the studies carried out by Melor and Ashairi (2014) and Ndibalema (2014) that teachers did not utilize most online applications like YouTube and other social media into their lessons. This finding is also relevant to the study by Marzilah and Sharifah Nadia (2010) regarding the way teachers normally prefer to teach Literature lessons.

This research also looks into the possible challenges or problems faced by teachers in using ICT in their Literature lessons. The results show that teachers have positive attitudes to employ ICT in their Literature lessons, however, they faced several challenges that may hinder their intention to use ICT. The majority of the respondents cited inaccessible and unavailable internet access as the major challenge that put a stop to teachers' intentions on using ICT tools. Not enough or even outdated and incompatible ICT software and hardware were also challenges faced by the teachers. These findings are in line with the studies by Ndibalema (2014) that teachers could employ the use of ICT if there are adequate resources and infrastructures. Hennessy et. al. (2010) also stated that if technology cannot be accessed by the teacher, then it will not be used. Lack of time is also one of the challenges to using ICT in the classroom. This is in line with the study by Becta (2004) as cited in Bingimlas (2009) that stated the problem of lack of time exists for teachers in many aspects of their work. Also, in Bee and Chia (2008), it is shown that to ensure any ICT to be used frequently and effectively, teachers' needs in using these ICT should be supported. In other words, unless the challenges are addressed, the attitudes of teachers in using ICT in Literature lessons will not be improving anytime soon.

\section{Conclusion, Implications \& Recommendation}


This study investigated the ICT usage among ESL teachers and their attitudes towards ICT in Literature lessons. It was found that almost all the respondents hold positive attitudes towards ICT though the actual use of ICT tools in the teaching and learning process is not so widespread. Also, the challenges reported by the teachers should be taken into consideration if the integration of ICT in Literature lessons to be a success.

The findings of this study could be specific only to the ESL teachers in Sarawak education but there is also a possibility that the implications of this study are significant to all ESL teachers in Malaysia. As a suggestion, if it could, that the teachers' workload outside of the teaching matters be reduced so as to provide more time for the teachers to prepare their lessons. Teaching always is and should be the core business of teachers and they should not be bothered by paperwork or the endless form-filling work. It should be understand that in order for teachers to fully integrate the use of ICT into their teaching, they need a lot of time to plan and construct these ICT-related lessons. This is especially needed by those teachers who are not competent with ICT but acquire the intention to use it in their lessons. And so, other administrative workload should be reduced to further support the use of ICT among teachers in their teaching. Teachers, on the other hand, should continuously put variations into their teaching methods and try to frequently include the use of ICT in their lessons. It should be noted that perhaps more campaigns or steps needed to be taken by the Ministry of Education in Malaysia or Sarawak's State Department of Education to encourage wider usage of ICT tools in the learning of Literature component especially in Sarawak schools. More courses related to the use of ICT in Literature lessons should be organized to encourage its use in the teaching and learning of the English Literature component and at the same time improve teachers' attitudes regarding ICT usage.

Since this study was a pure quantitative study, by just employing the use of a questionnaire as the medium of data collection, it is suggested that future research could employ other data collection instruments like interviews and classroom observations so as to collect a more in-depth information regarding the teachers' attitudes and especially to understand more on the challenges that they encountered in using ICT in teaching literature lessons.

\section{References}

Abedalaziz, N., Shahrir Jamaluddin \& Chin, H. L. (2013). Measuring Attitudes toward Computer and Internet Usage among Postgraduate Students in Malaysia. TOJET: The Turkish Online Journal of Educational Technology 12(2): 200-214 Retrieved from http://www.tojet.net/articles/v12i2/12219.pdf

Albirini, A. (2004). An Exploration of the Factors associated with the attitudes of high school EFL teachers toward Information and Communication Technology (Doctoral dissertation, The Ohio State University). from https://etd.ohiolink.edu/!etd.send_file?accession=osu1092688797\&disposition=inline

Albirini, A. (2006). Teachers' attitudes toward information and communication technologies: the case of Syrian EFL teachers. Computers \& Education 47: 373-398 Retrieved from 
http://www.pgce.soton.ac.uk/ict/SecondaryICT/PDFs/teacherattitudesEFLSyria.pdf http://dx.doi.org/10.1016/j.compedu.2004.10.013

Almaghlouth, O. A. (2008). Saudi Secondary School Science Teachers' Perceptions of the Use of ICT Tools to support Teaching and Learning. (Master's thesis, University of Waikato). Retrieved from http://researchcommons.waikato.ac.nz/bitstream/handle/10289/2432/thesis.pdf?sequence=1\& isAllowed $=\mathrm{y}$

Ashairi Suliman \& Melor Md Yunus. (2014). The Re-Introduction of English Literature Subject in Malaysian Secondary Schools: Urban versus Rural Teachers. Journal of Education and Human Development 3(2): 943-935 Retrieved from http://aripd.org/journal/index/jehd/vol-3-no-2-june-2014-abstract-57-jehd

Bee, T. L. \& Chia, H. S. (2008). Exploring the extent of ICT adoption among Secondary School Teachers in Malaysia. International Journal of Computing and ICT Research 2(2): 19-36 Retrieved from http://www.ijcir.org/volume2-number2/article 3.pdf

Bingimlas, K. A. (2009). Barriers to the successful integration of ICT in Teaching and Learning environments: A Review of the Literature. Eurasia Journal of Mathematics, Science and Technology Education 5(3): 235-245. Retrieved from http://www.ejmste.com/v5n3/eurasia_v5n3_bingimlas.pdf

Cahyani, H. \& Cahyono, B. Y. (2012). Teachers' Attitudes and Technology Use in Indonesian EFL Classrooms. TEFLIN Journal 23(2): 130-148. Retrieved from http://journal.teflin.org/index.php/teflin/article/viewfile/297/243

Chacko, J. (2007). ESL Learners' Perceptions towards the Learning of Literature in English. (Master's Thesis, University Putra Malaysia). Retrieved from http://psasir.upm.edu.my/4739/2/FBMK_2007_6.pdf

Chua, Y. P. (2012). Asas Statistik Penyelidikan (2 ${ }^{\text {nd }}$ ed.). Malaysia: McGraw-Hill (Malaysia) Sdn. Bhd.

Creswell, J. W. (2014). Educational Research: Planning, Conducting and Evaluating Quantitative and Qualitative Research $\left(4^{\text {th }} \mathrm{ed}\right)$. United States of America: Pearson Education Limited

Fauziah Ahmad \& Jamaluddin Aziz. (2009). Students' Perception of the Teachers' Teaching of Literature Communicating and Understanding through the Eyes of the Audience. European Journal of Social Sciences 7(3): 17-26. Retrieved from https://shidaedu702eportfolio.files.wordpress.com/2012/06/ejss_7_3_02.pdf

Fu, J. S. (2013). ICT in Education: A Critical Literature Review and Its Implications. International Journal of Education and Development using Information and Communication Technology (IJEDICT) 9(1): 112-125. $\quad$ Retrieved from https://ijedict.dec.uwi.edu/include/getdoc.php?id=5402 
Henessy, S., Harrison, D. \& Wamakote, L. (2010). Teacher Factors influencing Classroom Use of ICT in Sub-Saharan Africa. Itupale Online Journal of African Studies 2: 39-54. Retrieved from http://www.cambridgetoafrica.org/resources/hennessy\%20etal_final.pdf

Joseph, R. (2013). Teacher's views of ICT in EL classrooms in UAE institutes of Technology. (Master's Thesis, American University of Sharjah). Retrieved from https://dspace.aus.edu/xmlui/bitstream/handle/11073/5882/29.232-2013.01\%20-\%20Rajesh\% 20Joseph.pdf?sequence $=1$

Kandasamy, M. \& Parilah Hj. Mohd Shah. (2013). Knowledge, Attitude and Use of ICT among ESL Teachers. GSE Journal of Education: 185-199. Retrieved from http://worldconferences.net/proceedings/gse2013/papers_gse2013/247\%20Moganashwari\%2 0Kandasamy-Parilah\%20Bt\%20Hj.\%20Mohd\%20Shah.pdf

Kumar, R. (2011). Research Methodology: A Step-by-step guide for beginners $\left(3^{\text {rd }}\right.$ ed.). India: Sage Publications India Pvt. Ltd.

Marzilah A. Aziz \& Sharifah Nadia Syed Nasharudin. (2010). An Investigation on Approaches Used to teach Literature in the ESL Classroom: A Case Study of Sekolah Menengah Kebangsaan Taman Desan Skudai, Johor Bahru. Retrieved from http://core.kmi.open.ac.uk/download/pdf/11786469.pdf

Melor Md Yunus \& Ashairi Suliman. (2014). Information \& Communication Technology (ICT) Tools in Teaching and Learning Literature Component in Malaysia Secondary Schools. Asian Social Science 10(7): 136-152. Retrieved from http://ccsenet.org/journal/index.php/ass/article/view/35655/20195

Melor Md Yunus, Maimun Aqsha Lubis \& Chua, P. L. (2009). Language Learning via ICT: Uses, Challenges and Issues. WSEAS Transactions on Information Science and Applications 9(6): 1453-1467. Retrieved from http://www.wseas.us/e-library/transactions/information/2009/29-575.pdf

Melor Md Yunus, Norazah Nordin, Salehi, H., Mohamed Amin Embi \& Salehi, Z. (2014). Future of ICT as a Pedagogical Tool in ESL Teaching and Learning. Research Journal of Applied Sciences, Engineering and Technology 7(4): 764-770. Retrieved from http://maxwellsci.com/print/rjaset/v7-764-770.pdf

Ministry of Education. (2012). Educational development plan 2013-2025. Kuala Lumpur.

Nair, G. K. S., Rozlan Abdul Rahim, Roszainora Setia, Aileen Farida Mohd Adam, Norhayati Husin, Sabapathy, E., ... Norhafiza Abu Seman. (2012). ICT and Teachers' Attitude in English Language Teaching. Asian Social Science 8(11):8-12. Retrieved from http://ccsenet.org/journal/index.php/ass/article/download/19793/13082.

Ndibalema, P. (2014). Teachers' Attitudes towards the Use of Information Communication Technology (ICT) as a Pedagogical Tool in Secondary Schools in Tanzania: The Case of Kondoa District. International Journal of Education and Research 2(2): 1-16. Retrieved from http://www.ijern.com/journal/February-2014/11.pdf 
Nor Hashimah Isa \& Che Ton Mahmud. (2012). Literary Texts for Malaysian Secondary Schools: Needs versus Policy. International Journal of Humanities and Social Science 2(7): 76-86. Retrieved from http://www.ijhssnet.com/journals/Vol_2_No_7_April_2012/9.pdf

Nur Aisyah Mohamad Noor, Zamri Mahamod, Afendi Hamat \& Mohamed Amin Embi. (2012). Persepsi Pelajar terhadap Aplikasi Perisian Multimedia dalam Pembelajaran Komsas Bahasa Melayu Tingkatan 1. Jurnal Pendidikan Bahasa Melayu 2(1): 1-16. Retrieved from http://www.ukm.my/jpbm/pdf/1-16.\%20Aisyah\%20et\%20al.pdf

Nyambane, C. O. \& Nzuki, D. (2014). Factors Influencing ICT integration in Teaching: A Literature Review. International Journal of Education and Research 2(3): 1-18. Retrieved from http://www.ijern.com/journal/March-2014/38.pdf

Oldfield, A. (2010). A Summary of Teacher Attitudes to ICT use in Schools. Retrieved from http://itec.eun.org/c/document_library/get_file?p_1_id=10307\&folderId=17990\&name=DLF E-1550.pdf

Papanastasiou, E. C. \& Angeli, C. (2008). Evaluating the Use of ICT in Education: Psychometric Properties of the Survey of Factors affecting teachers teaching with Technology (SFA-T ${ }^{3}$ ). Educational Technology \& Society 11(1): 69-86. Retrieved from http://ifets.info/journals/11_1/6.pdf

Saadiyah Darus \& Ho, W. L. (2014, September 29). Investigating teachers' Use of Computers in Teaching English: A Case Study. Retrieved from http://www.academia.edu/1637656/Investigating_teachers_use_of_computers_in_teaching_E nglish_A_case_study

Sabzian, F. \& Gilakjani, A. P. (2013). Teachers' Attitudes about Computer Technology Training, Professional Development, Integration, Experience, Anxiety and Literacy in English Language Teaching and Learning. International Journal of Applied Science and $\begin{array}{llllll}\text { Technology } & 3(1): & 67- & 74 . & \text { Retrieved } & \text { from }\end{array}$ http://www.ijastnet.com/journals/Vol_3_No_1_January_2013/9.pdf

Şahİn-Kizil, A. (2011). EFL Teachers attitudes towards Information and Communication Technologies (ICT). $5^{\text {th }}$ International Computer \& Instructional Technologies Symposium. Retrieved from http://web.firat.edu.tr/icits2011/papers/27786.pdf

Salehi, H. \& Salehi, Z. (2012). Integration of ICT in Language teaching: Challenges and barriers. $3^{\text {rd }}$ International Conference on e-Education, e-Business, e-Management and e-Learning 27: 215-219. from http://www.ipedr.com/vol27/40-IC4E\%202012-F10037.pdf.

Sánchez, A. B., Marcos, J. J. M., González, M. \& He, G. L. (2012). In service Teachers' attitudes towards the use of ICT in the classroom. Procedia - Social and Behavioral Sciences 46:1358-1364. Retrieved from http://www.sciencedirect.com/science/article/pii/S1877042812014310 http://dx.doi.org/10.1016/j.sbspro.2012.05.302 
Singh, T. K. R. \& Chan, S. (2014). Teacher Readiness on ICT Integration in Teaching-Learning-A Malaysian Case Study. International Journal of Asian Social Science 4(7): 874-885. Retrieved

from

http://www.aessweb.com/pdf-files/ijass-2014-4\%287\%29-874-885.pdf

Siti Norliana Ghazali, Roszainora Setia, Muthusamy, C. \& Kamaruzaman Jusoff. (2009). ESL Students' attitudes towards Texts and Teaching Methods Used in Literature Classes. English Language Teaching 2(4): 51-56. Retrieved from http://www.ccsenet.org/journal/index.php/elt/article/viewFile/4445/3786

Al-Zaidiyeen, N. J., Leong, L. M. \& Fong, S. F. (2010). Teachers' Attitudes and Levels of Technology Use in Classrooms: The case of Jordan Schools. International Education Studies $3(2)$ : 211-218.

Retrieved

from

http://www.ccsenet.org/journal/index.php/ies/article/viewFile/5891/4664

http://dx.doi.org/10.5539/ies.v3n2p211

\section{Copyright Disclaimer}

Copyright for this article is retained by the author(s), with first publication rights granted to the journal.

This is an open-access article distributed under the terms and conditions of the Creative Commons Attribution license (http://creativecommons.org/licenses/by/3.0/). 